\title{
Revisiting deforestation in Africa (1990-2010): One more lost generation
}

\author{
Jean-Roger Mercier
}

\begin{abstract}
This spotlight revisits the dynamics and prognosis outlined in the late 1980's published in Déforestation en Afrique. This book on deforestation in Africa utilized available statistical data from the 1980's and was a pioneering self-styled attempt to provide a holistic viewpoint of the ongoing trends pertaining to deforestation in Africa; of root causes and of the challenges facing the conservation community. Here, the same author searches for an explanation for the 'commercial fiasco' of that book and uses the recent Global Forest Resource Assessment (GFRA) published by the Food and Agriculture Organisation (FAO, 2010), concluding that (i) this overall prognosis turned out to be slightly pessimistic vs. the actual forest evolution as recorded by $\mathrm{FAO}$, but that (ii) deforestation in Africa still continues at $0.5 \%$ per annum, and (iii) success stories are few and Africa remains the continent where major deforestation continues apace. The analysis of ten African countries 'at risk' because of a combination of an economic slump coupled with a high deforestation rate confirms a likely relationship between these two factors. The lack of attention paid to deforestation in Africa raises concerns that "throwing money at the problem" - the best solution that the international community has found so far - may not be constructive in the least.
\end{abstract}

\section{RÉSUMÉ}

Un livre publié en 1991, écrit par l'auteur utilisait les données statistiques des années 80 sur les forêts Africaines, données telles que disponibles à l'époque. Ce livre représentait une première tentative, non sollicitée, de fournir un tableau holistique des tendances d'alors sur la déforestation en Afrique, de s'interroger sur les causes profondes de ce phénomène et sur les défis à relever dans ce domaine. Dans le présent article, I'auteur cherche les raisons du fiasco commercial du livre et effectue des calculs sur les données les plus récentes sur les forêts Africaines telles que publiées par l'Organisation des Nations-unies pour l'agriculture et l'alimentation (plus connue sous son sigle anglais FAO). Les principales conclusions de cette rapide analyse sont (i) les projections sur le futur des forêts Africaines effectuées dans le livre de 1991 se révèlent marginalement pessimistes par rapport à la réalité observée (sur la base des projections de 1991 et sur une base 100 en 1990, les forêts africaines restantes seraient dans une fourchette de 77,2 à 87,8\%, l'indice réel étant 89,9\%), cependant, (ii) la

\author{
Cyberoustal \\ Mas de l'Olivière, Chemin de Taxo \\ 66690 Saint André, France \\ E-mail: jeanrogermercier@yahoo.fr
}

déforestation continue en Afrique à un rythme de 0,5\% I'an, peu différent du taux de 0,56\% dans les années 90 et (iii) les réussites Africaines dans la lutte contre la déforestation sont peu nombreuses et ce continent reste le plus exposé à ce fléau dans le monde. Le livre de 1991 contenait également l'identification de dix pays Africains «à risque » à cause d'un cumul de stagnation économique et de fort taux de déforestation. L'observation des évolutions récentes confirme que ces pays sont « mal partis ». En conclusion, l'auteur regrette le manque d'attention à la déforestation en Afrique, au moment même où le monde célèbre « Rio + 20 »; I'auteur craint également que la tactique habituelle de la communauté internationale « jeter de l'argent sur le problème » ne fonctionne pas, des causes fondamentales de la déforestation comme le manque de politiques publiques efficaces ou la corruption endémique réclamant plus que de l'argent pour être extirpées.

\section{'DÉFORESTATION EN AFRIQUE'}

The book Déforestation en Afrique (Mercier 1991) outlined the basic features of African forests, available statistics pertaining to these forests, and the common uses of forest products and services, in both a local and global context. A chapter on forests in relation to development described the vicious circle linking stagnant poverty with resource degradation (specifically deforestation) in Africa. Mercier (1991) also outlined future scenarios of deforestation and identified ten African countries particularly at risk when it comes to environmental degradation coupled with a stagnant, impoverished economy. He concluded the book with a set of broad-based policy recommendations.

commercially the book was a disaster, in contrast to a couple of books the same author had written during the preceding decade. The first book (Mercier 1978) is regarded as having had healthy sales in spite of being just as difficult to read and it dealt with a more provincial topic (Mercier 1978). Why then, was interest so low in Déforestation en Afrique? A possible cause may have been a low quality of writing (though this is no different from the 1978 book), much of the explanation can be found in the following cumulative factors:

- A slow start and slow development of a systematic approach of centralised forest knowledge (including field data collection and processing) for Africa by the international community; 
- a low point in terms of environmental concerns (the 1973 energy shock had passed, liberalism was booming and the 'environmental fiesta' in Rio and the baptism of 'sustainable development' were still under preparation);

- a lack of interest on the part of francophone readers for world (including African) matters;

- the lack of academic and other institutional support for Mercier's 1991 book;

- lack of support for the book meant that Mercier (1991) was unable to fully explore and research preliminary documentation on the topic particularly outlining the complexity of deforestation in Africa;

- a key finding was the lack of appropriate and consistent measurement of deforestation, particularly in Africa. Another key finding was the lack of sensitivity of decision-makers to multi-sectoral approaches to the deforestation phenomenon.

\section{REVISITING 'DEFORESTATION IN AFRICA'}

Twenty years later, most of the progress has been on the studies and measurements of deforestation in Africa and Madagascar, but the deforestation itself continues: in some places - especially in the strategic Congo Basin - on primary forests in an irreversible manner. The questions that come to mind while revisiting the 1991 book are "how predictable were deforestation trends during the late 1980's and how many of these predictions materialised?" In 2012, courtesy the UN system and modern technology, improved knowledge about forests and deforestation trends worldwide and particularly in Africa, is 'a mouse click' away from any analyst. For this spotlight, I have accessed FAO's Global Forest Resource Assessment database (FAO 2012) to compare notes with what I had written up in the late 1980's.

I had hoped that the said assessment would be of the same accuracy as the Millennium Ecosystem Assessment (2005) which mobilized over 1,310 experts into action and led to millions of \$US being spent, only to realize that GFRA was actually based on a set of questionnaires sent by FAO to individual governments. The statistical tables that were used for this article was compiled from that data. The compilation was more comprehensive than the 1982 data that what was used in preparation of the 1991 book (Mercier 1991), but it was still not based on thorough field studies. So, while the 2012 GFRA figures are more comprehensive than the 1982 FAO figures, we are still far from having an accurate representation of forest cover, forest quality and forest loss in Africa.

one key trend was noted during the preparation of the 1991 book: the annual rate/extent of forests on a country-by-country base. By 1982, the total forest cover estimated was about 640 Mha for the 42 countries that had produced some data on the status of their forests. A key distinction was made between open and closed forest cover. According to Neeff et al. (2006) "a forest may consist either of closed forest formations where trees of various storeys and undergrowth cover a high proportion of the ground, or open forest". Closed forests are the 'ecologist's dream', since they are richest in terms of biodiversity and have kept their ecological assets more or less intact (e.g., Wright and Muller-Landau 2006, Foley et al. 2007). The split between the estimated extent of closed and open forests was 31/69 in terms of Africa on a continental level.

In the much more factual and comprehensive recent global forest assessment, the African 'countries' (the presence of Mayotte, La Réunion and Western Sahara included in the list) for which data were measured and compiled, the overall forest cover for 1990 was given as being 749 Mha. The difference between the FAO 1982 and the 2012 estimates are a combination of

- unreported forestry data in some key countries in 1982 (e.g., no reported extent of open forest area in South Africa, then in full apartheid mode) and

- absence of about a dozen countries, including most of the islands around Africa, in the 1982 FAO compilation. For the purpose of the present article, a relative comparison will help establish how much of Mercier's 1991 prognosis was accurate or inaccurate.

While the 2000 reality was close to 1991 book's projections (actual index is 94.7 and the figures from the 1991 book are 91.6-95.7), the 2010 reality ( $89.9 \%$ of the 1990 forests remaining in Africa) is less pessimistic than the book's 77.2-87.8\% estimate. Indeed, the recent FAO figures show a very slight decrease in annual deforestation rate on the continent from the 1990 's (0.56\% per annum) to the 2000 's ( $0.50 \%$ per annum). This decrease in degradation rate

- is hardly statistically significant and

- has little bearing of the future evolution of African forests (forest cover projection in 2050 is 555 Mha for $0.5 \%$ and $535 \mathrm{Mha}$ for $0.56 \%$ ). This very slight reduction in rate of degradation is not commensurate with the huge amount of public resources that have been invested in forest management in Africa during the last two decades. FAO (2010) mentions yearly spendings of 361 M \$US in 2000 and 578 M US\$ in 2005 (most recent figure available).

There are four basic motivations to this revisiting: - Relevance of forests for sustainable development in Africa - The obvious failure of public policies in protecting the remaining forests in Africa

- Deforestation as a reflection of incompetent resource management

- The long journey before we have a clearer picture of deforestation.

Forests, open or closed, play an important role in sustainable development in Africa. Closed forests are particularly vulnerable because of the irreversible nature of their destruction, and have been often heralded by the Big Non Governmental Organisations (BINGOS) as being of particularly key significance on various levels, but open forests also play an important role, not just as carbon sink, but also as providers of vital products and services to local human populations (Falconer 1990, Ambrose-Oji 2003, Ticktin 2004, Topa 2005). This has been demonstrated on a subregional basis (Cleaver 1992) as well as on a regional scale. The authors of "The changing wealth of nations" (World Bank 2011), for instance, estimate that, for Sub-Saharan Africa as a whole, Non-Timber Forest (NTF) asset value was $44 \%$ of timber value in 1995 and $83 \%$ in 2005, respectively. 
On the failure of forest conservation policies, I have possibly been too impressed by 'experts' or economists whom I had met in international circles, many of them claiming that they had found - and helped to implement - the solution to sustainable forest development. The reality, unfortunately, is that deforestation in Africa continues, whether at the rate of the FAO/GFRA tables, or not. Ergo, public policies have failed in most African countries. The struggle for practices and policies that actually conserve forests and their assets on the ground has to continue.

Deforestation is just one facet of incompetent and shabby resource management at the local, national and sub-regional level. Whether 'effective' policies or not are designed by African countries or by the international community, what matters is what happens in the field. This holds true for forest/tree management and for other natural resource management. In the field, a combination of low public service presence and of generalised corruption involving both the corrupters and the corrupted, minimises impact of policy implementation. This was well illustrated in the case of rosewood exploitation in Madagascar (Randriamalala et al. 2011, Schuurman and Lowry 2009).

Last but not least, the new forest statistics as presented in FAO's 2012 GFRA - while they are more detailed than 1982's figures - still lack the accuracy and consistency needed to properly understand deforestation and sustainable forest management. This gap ought to be dealt with rapidly, especially since data collection technology is evolving fast, e.g., with the increased use of new sensors (Tucker and Townshend 2000, Achard et al. 2002, Murphy 2009).

\section{TWENTY YEARS OF DEFORESTATION}

My first conclusion for this spotlight: as was predicted in Mercier's 1991 book (Mercier 1991), the situation for Africa's forests worsened between 1990 and 2010. Of practically all parts of the world (except Central America, which has a whopping $-1.23 \%$ per annum), Africa has had, during the $2005-2010$ period, the highest deforestation rate: an average of $-0.5 \%$ per annum, while Asia experiences a net growth during the period (+0.29\% per annum, largely due to forest plantation efforts in China (Liu and Diamond 2005, Turnbull 2007), Latin America (-0.41\% per annum) loses forest, but less rapidly than Africa and more than Oceania $(-0,31 \%$ when Australia is removed from the statistics. Australia has a high deforestation rate $(-0.61 \%)$ and more than $75 \%$ of the forest cover in Oceania.). However, decrease of forest cover in Africa between 1990 and 2010 was slightly smaller than what Mercier (1991) originally suggested.

Second conclusion: the tables have turned. Several of the worst 'culprits of deforestation' have actually become noticeable guardians of the forests (the ratio 'deforestation rate 2002-2010/deforestation rate 1982' was used as a guide), while in other countries, the reverse seems to have occurred. Tunisia, Rwanda and Morocco now have a net positive forest cover growth. Other countries (Mauritania, Mozambique, Benin, Burkina Faso, Burundi, Sudan, Niger, Madagascar, Liberia, Malawi, Algeria, and Kenya) have experienced a substantial decrease in their deforestation rate. In the remaining African countries deforestation rates have worsened. With appropriate resources, a finer analysis would look at positive and negative cases and learn from the policies that have been put in place. In passing, it may be worth noting that Gabon, consistent with the Bongo family's dislike for statistics, has produced amazing reports on its forest cover: a consistent (and suspiciously rounded figure) between 2000 and 2010.

Third conclusion: Mercier (1991) proposed a set of criteria to identify countries 'at risk' in Africa - key factors included low income per capita, low literacy, high pressure on arable land and low forest cover. The 1991 prediction was based on a multi-criteria analysis involving five variables (GDP per capita, Illiteracy rate, Ratio Forest area/land area, Forest area/capita, Population/area balance, and a ratio by FAO relating the actual per country agricultural land availability per capita with an 'ideal' reference ratio).

Based on the compilation of these variables for the 42 countries assessed, Mercier (1991) identified the following ten countries as being most at risk in terms of forest loss: Malawi, Chad, Nigeria, Rwanda, Gambia, Somalia, Burundi, Burkina Faso, Mauritania, Niger, in increasing order of risk (i.e., Niger being the most at risk). The 2010 statistics actually confirmed this. The ten countries, on the average, are $40 \%$ under the average 2010 GDP/capita in Africa. If Nigeria, a large country with its $150+$ million inhabitants, is removed from the list, the nine remaining countries have a GDP/capita of $67 \%$ below the continental average.

In summary the 1991 projections and guestimates (Mercier 1991) were far from wrong. The impact of alarm bells was extremely low, and the same African deforestation problem as in the late 1980's still lies ahead, only much worse so. Would a new answer be acronyms and money? In the early 1990's, international development experts could simply mention the Tropical Forest Action Plan (TFAP) and, later, an oversubscribed Congo Basin Forest Fund. What will the new answers be?

\section{AS A MATTER OF CONCLUSION}

The 1991 book (Déforestation en Afrique) is the work of a lone ranger and, at the end of the day the accuracies or inaccuracies in the book matter little, since no-one really acted to the findings and recommendations. At the very least, I would ensure that a new book's conclusions would be vetted by a multidisciplinary panel of scientists and practitioners.

Secondly, during the drafting of a new version of that book, I would take a much harder and closer look at the economic, social, environmental and cultural roles that trees and forests play in the daily life of ordinary African people, including, but not limited to, forest-dependent people. I would review the multiple ex-post evaluations made of community forest management projects and programs as well as of logging certification and control practices. Last but not least, I would analyse the fate of primary forests, focusing on specific, concrete trends and situations. For instance, much more attention would be paid to certain very worrying situations, like the whopping $2.94 \%$ of per annum primary forest loss in Central African Republic (CAR). Once raised to an empire status, with the complicity of several western governments, France being unfortunately in the lead, CAR is now distanced from international public attention and away from the main air traffic zones. According to FAO figures, the annual rate of primary forest destruction in CAR increased from $2.16 \%$ during the 1990 's to $2.94 \%$ during the 2005-2010 period. If that latter rate remains constant, half of the CAR primary forest, or 1.2 Mha, will be lost during the coming two decades - more so if the deforestation rate continues to increase. I would also classify the primary forest in Nigeria as 
nonexistent, as it decreased from 1.5 Mha in 1990 to a 'non significant' level in 2010.

Thirdly, I would ensure that the published version, using the Internet, floods the large institutions and the BINGOs with recommendations put across in such a shocking manner that reactions would be essential and would have to go on record Deforestation is too serious an issue to be handled by foresters alone, and it does concern all decision makers interested in the fate of Africa.

A cynic might say "20 years ago, we tried to blow the whistle on a possibly unwell patient (forests in Africa). In 2012, we now have the confirmation that the patient is very sick. Is that progress? The war against deforestation continues. The army is small and does not have adequate weaponry. Tons of cash will pour on green carbon funds and new forests/plantations will be planted and nurtured. But what about the forests for the people, forests that shrink due to land grabbing, timber traffickers, and the greed of the new Asian barons? My hopes are that twenty years later into the 21st century, more positive news can be reported...

\section{REFERENCES}

Achard, F., Eva, H. D., Stibig, H.-J., Mayaux, P., Gallego, J., Richards, T. and Malingreau, J.-P. 2002. Determination of deforestation rates of the world's humid tropical forests. Science 297: 999-1002. (doi:10.1126/ science.1070656)

Ambrose-Oji, B. 2003. The contribution of NTFPs to the livelihoods of the 'forest poor': evidence from the tropical forest zone of south-west Cameroon. International Forestry Review 5, 2: 106-117.

Cleaver, K. 1992. Deforestation in the western and central African forest: the agricultural and demographic causes, and some solutions in Conservation of west and central African rain forests. Proceedings of the Conference on Conservation of West and Central African Rain Forest, Abidjan, 5-9 November 1990. World Bank Environment Paper N. 1. The World Bank, Washington D. C.

Falconer, J. 1990. The major significance of 'minor' forest products: The local use and value of forests in the West African humid forest zone. FAO Community Forestry Note, Rome.

FAO 1982, 2012. Global forest resource assessment, outcome available at <http://countrystat.org/index.asp?ctry=for\&HomeFor=for $>$ downloaded 01/05/2012.

FAO 2010. Global forest resource assessment, Main Report. FAO Forestry Paper 163, Rome.

Foley, J. A., Asner, G. P., Costa, M. H., Coe, M. T., Ruth Defries, R., Gibbs, H. K., Howard, E. A., Olson, S., Patz, J., Ramankutty, N. and Snyder, P. 2007. Amazonia revealed: forest degradation and loss of ecosystem goods and services in the Amazon Basin. Frontiers in Ecology and the Environment 5: 25-32. (doi:10.1890/15409295(2007)5[25:ARFDAL]2.0.CO;2)

Liu, J. and Diamond, J. 2005. China's environment in a globalizing world. How China and the rest of the world affect each other. Nature 435:11791186. (doi:10.1038/4351179a)

Neeff, T., von Luepke, H. and Schoene, D. 2006. Choosing a forest definition for the Clean Development Mechanism, Forest and Climate Change Working Paper 4, Rome. <http://www.fao.org/forestry/1128003f2112412b94f8ca5f9797c7558e9bc.pdf> downloaded 01/05/2012

Mercier, J.-R. 1978. Énergie et Agriculture : le Choix Écologique. Éditions Debard, Paris.

Mercier, J.-R. 1991. La Déforestation en Afrique. EDISUD, Paris.

Michel, S. \& Beuret, M. 2008. La Chinafrique, Pékin à la Conquête du Continent Noir. Grasset, Paris.

Millennium Ecosystem Assessment. 2005. Guide to the Millennium Assessment Reports. <http://www.maweb.org/en/index.aspx> accessed on 1 March 2012
Murphy, G. 2009. New Sensor Technologies for Forest Data Collection, in Meeting Multiple Demands for Forest Information: New Technologies in Forest Data Gathering. IUFRO Conference, Mount Gambier.

Randriamalala, H., Rasarely, E., Ratsimbazafy, J., Brizzi, A., Ballet, J. Razakamanarina, N., Ratsifandrihamanana, N. \& Schuurman, D. 2011. Stocks de bois précieux de Madagascar - quelle voie emprunter? Madagascar Conservation \& Development 6, 2: 88-96.

Schuurman, D. and Lowry II, P. P. 2009. The Madagascar rosewood massacre. Madagascar Conservation \& Development 4, 2: 98-102.

Ticktin, T. 2004.The ecological implications of harvesting non-timber forest products. Journal of Applied Ecology 41, 1:11-21. (doi:10.1111/j.13652664.2004.00859.x)

Topa, G. 2005. Framework for forest resource management in Sub-Saharan Africa. Africa Region Working Paper Series Number 89, Washington D.C. <http://www.worldbank.org/afr/wps/wp89.htm> downloaded 01/04/2012

Tucker, C. J. and Townshend, J. R. G. 2000. Strategies for monitoring tropical deforestation using satellite data. International Journal of Remote Sensing 21, 6-7: 1461-1471. (doi:10.1080/014311600210263)

Turnbull, J. W. 2007. Development of sustainable forestry plantations in China: a review. Impact Assessment Series Report N. 45, Canberra. <http://aciar.gov.au/files/node/2418/IAS45.pdf> accessed 1 March 2012.

World Bank 2011. The Changing Wealth of Nations: Measuring Sustainable Development in the New Millennium. World Bank, Washington D. C.

Wright, S. J. and Muller-Landau, H. C. 2006. The future of tropical forest species. Biotropica 38, 3: 287-3011. (doi:10.1111/j.17447429.2006.00154.x) 